\title{
The In vivo Trend Analysis of Kidney Function Indices and Lipid Profile of Albino Rats Administered Palm-Wine
}

\author{
G. S. Haruna, M. O. Enemali, O. B. Asogwa, M. H. Sani, and B. A James
}

\section{ABSTRACT}

\begin{abstract}
The present study evaluated the dynamics of kidney function indices and lipid profile of albino rats after administration of palm-wine to them. The fresh palm-wine was collected from a local palm-wine tapper on daily basis and divided in to two portions. The first portion was labelled "Fresh palmwine" and administered $(15 \mathrm{ml} / \mathrm{kg})$ to group 2 and $(30 \mathrm{ml} / \mathrm{kg})$ to group 4 , the second portion was allowed to ferment for additional ten hours and labelled "prolonged-fermented palm-wine" and administered $(15 \mathrm{ml} / \mathrm{kg})$ to group 3 and $(30 \mathrm{ml} / \mathrm{kg})$ to group 5 . Group one served as the control and received distilled water, all for 28 days. Each group was randomly allocated four rats. Results $(\mathbf{m m o l} / \mathrm{ml})$ revealed a significantly $(\mathbf{p}<0.05)$ lower concentration of urea $(\mathbf{1 0 . 2 1} \pm \mathbf{0 . 4 0})$, higher creatinine $(0.37 \pm 0.17), \mathrm{K}+$ $(4.06 \pm 0.06)$ and $\mathrm{Cl}^{-}(86.12 \pm 4.61)$ in group 2 when compared to the control; $11.035 \pm .110,0.395 \pm 0.06,3.945 \pm .064,80.090 \pm 0.25$ respectively. In group 3 , the concentrations of urea $(11.70 \pm 0.35)$, creatinine $(0.42 \pm 0.12)$ and $\mathrm{Cl}^{-}$ $(88.57 \pm 0.50)$ were significantly $(p<0.05)$ higher when compared to the control. $\mathrm{Na}^{+}(120.09 \pm 10.40)$ was significantly $(\mathrm{p}<0.05)$ higher in group 4 when compared to the control $(100.065 \pm 0.75)$. TAG (in $\mathrm{mg} / \mathrm{dL})(2.18 \pm 0.10)$ was significantly $(p<0.05)$ higher in group 2 compared to control (1.96 \pm 0.023$)$. T. cholesterol $(3.125 \pm 0.27)$ and LDL-C (1.64 \pm 0.47$)$ were significantly $(p<0.05)$ lower in group 3 compared to the control; $1.99 \pm 0.052$, respectively with significantly $(p<0.05)$ elevated HDL $(1.11 \pm 0.22)$ compared to control $(0.840 \pm 0.092)$. TAG $(2.190 \pm 0.25)$ and HDL-C $(1.15 \pm 0.23)$ increased significantly $(\mathrm{p}<0.05)$ while LDL-C $(1.58 \pm 0.14)$ decreased significantly $(p<0.05)$ in group 4 compared to control; $1.960 \pm 0.023$, $0.840 \pm 0.092,1.985 \pm 0.052$ respectively. $T$. cholesterol $(2.93 \pm 0.08)$ and LDLC $(1.56 \pm 0.03)$ decreased significantly $(p<0.05)$ with $\operatorname{significant}(p<0.05)$ increase in HDL-C $(0.99 \pm 0.10)$ in group 5 compared to the control. Fresh and prolonged-fermented palm-wine may adversely affect kidney function indices and lipid profile.
\end{abstract}

Keywords: Administration, Alcoholic, fermentation, fresh palm-wine Microorganisms.

\section{INTRODUCTION}

The alcoholic drink commonly referred to as "Palm-wine" is a product of natural fermentation process which is gotten from different species of palm trees by a process known as "palm-wine tapping". The palm-wine tapping process involves cutting through the palm tree and allowing the sugary sap to ooze out while the fermenting organisms feed on the sugar in the sap and eventually converting it to an alcoholic solution that is usually enjoyed by the consumers. The fermentation process may involve lactic acid bacteria, yeast and acetic acid bacteria, as well as Zymomonas and Leuconostoc which are normal flora of the sap [1]-[3]. The types and number of organisms involved may vary widely, even from tree to tree depending on the prevailing environmental conditions [4]. The fermentation of raphia palm wine for instance is considered an in-expensive and
Published Online: March 22, 2021

ISSN: $2684-5199$

DOI: 10.24018 /ejbio.2021.2.2.160

\section{G. S. Haruna*}

Department of Biochemistry and Molecular Biology, Nasarawa State University, Keffi, Nigeria.

(e-mail: sundayharuna ${ }^{\circledR}$ nsuk.edu.ng) M. O. Enemali

Department of Applied Biochemistry, Nnamdi Azikiwe University, Awka, Anambra State, Nigeria.

(e-mail: moenemali@unizik.edu.ng)

O. B. Asogwa

Department of Biochemistry and Molecular Biology, Nasarawa State University, Keffi, Nigeria.

(e-mail: adorerbonavec@gmail.com) M. H. Sani

Department of Plant Science and Boitechnology, Nasarawa State University, Keffi, Nigeria.

(e-mail: mhsloko26@gmail.com)

B. A. James

Department of Biochemistry and Molecular Biology, Nasarawa State University, Keffi, Nigeria.

(e-mail: benjaminjamesakun@gmail.com)

*Corresponding Author

effective means of palm wine production in Nigeria. Usually, the conversion of fresh palm sap to palm-wine is timedependent. At the onset of the tapping process, not much of the sap would have been converted to the wine (alcoholcontaining) but as the time proceeds, more of the sap are converted to the wine. Hence the longer the fermentation process, the more alcoholic the wine becomes. One of the major biochemical and health challenges of the fermentation process is that Bacteria and yeasts usually contaminate the juice as it is tapped and there are changes in biochemical composition of the palm wine. Previous studies on the microbiology of E. guineensis and $R$. hookeri have incriminated several bacteria and yeast flora to be involved in the fermentation process [2]. Lactic acid bacteria (LAB) are responsible for many fermented foods such as sauerkraut, pickles and yogurt. They have also been isolated from palm wines at various stages of fermentation. Many species of $\mathrm{LAB}$ do not conduct malolactic fermentation and their growth 
in wine can cause some serious wine spoilage [4]. The health effect of which may be observed as symptoms after consuming the wine. The types of lactic acid bacteria usually found in palm wine may belong to three genera, namely Leuconostoc - Heterofermentative cocci, oval or spherical, occur in pairs or chains. Pediococcus - Homofermentative cocci, often found in tetrads. Lactobacillus Homofermentative or heterofermentative rods, found singly or in chains.

The organisms are gram positive, catalase negative, nonsporing cocci, coccobacilli, or rods. They are microaerophilic, implying that they grow well under conditions of low oxygen content. Since they can grow under low oxygen conditions, they can grow throughout the wine (as opposed to on the surface of the wine) even though the container is kept full. The bacteria can metabolize sugars, acids and other constituents in wine and produce several compounds. Some of these are undesirable and constitute spoilage.

When the fermentation by the natural microbial flora has occurred, the sugar level decreases rapidly as it is converted to alcohol and other products [5]. Whereas the sap becomes milky-white due to the increased microbial suspension resulting from the prolific growth of the fermenting organisms [1]. During fermentation, more complex sugar such as sucrose is hydrolyzed to glucose and fructose. Reducing sugar is found only in trace amounts at the beginning and increases as sucrose is hydrolyzed. During the first $24 \mathrm{hrs}$, more than half of the total sugars in the sap are fermented, with sucrose always used most rapidly. At this time, many conscious consumers may stop fermentation with the $\mathrm{pH}$ about 5. Acetic and lactic acids are produced along with ethanol during fermentation. After about 36 to $48 \mathrm{hrs}$, the concentration of ethanol reaches a maximum of 5.0 to $5.28 \%$ $\mathrm{v} / \mathrm{v}$; the concentration of ethanol soon starts to increase in the palm wine as it has been stored for a longer period.

A $\mathrm{pH}$ of about 7.2 in the original palm sap is usually observed and after $8 \mathrm{~h}$, it may fall between 5.5 and 5.8, at which stage of fermentation by the yeast Saccharomyces cerevisiae is most vigorous [1]. By the time the alcoholic content is about $5.0 \%$, the $\mathrm{pH}$ may have fallen to around 4.0 to 4.3. Faint sulphur-like odor may also be perceived.

The bacteria that are most predominant in palm wine after fermentation are Micrococcus, Leuconostoc, Lactobacillus and Acetobacter; while the predominant yeasts usually identified are Saccharomyces and Candida spp. Palm-wine is also known to possess some level of health benefits sterning from its antioxidant properties by improving sight, a claim that is usually attributed to its vitamin $C$ content [1]. A study by [6] showed a favorable trend of liver and antioxidant enzymes in albino rats when administered palm-wine. The types of bacteria present appear to depend on the stage of fermentation and the composition of the sap [7]. Due to the overwhelming nature of the metabolic activities and changes that occur during the fermentation process and the possibility of predisposing consumers to unbearable feelings, there is need to evaluate the metabolic effect of consuming the freshly tapped and prolonged-fermented palm-wine. In this study, the kidney function parameters as well as lipid profile indices were analyzed in vivo using albino rats as the animal models.

\section{MATERIALS AND METHOdS}

\section{A. Materials}

Palm Wine: Freshly tapped palm wine was purchased from a local palm wine tapper in Keffi town on a daily basis for the thirty (30) days. The fresh palm wine was collected into a plastic keg and covered tightly. It was then transported to the laboratory and stored at room temperature before the experiment.

Experimental Animals: Adult male albino rats with body weight ranging from $150-250 \mathrm{~g}$ were used in this study. They were purchased from the animal house of University of Jos, Plateau state, Nigeria. They were transported in cages to animal house of the Department of Biochemistry and Molecular Biology, Nasarawa state university Keffi. They were acclimatized for seven (7) days of $12 \mathrm{~h}$ light and $12 \mathrm{~h}$ night cycle and allowed free access to feed and water ad libitum prior to the commencement of the research.

Chemicals/Reagents: All chemicals used for this study were of analytical grade and products of May and Barker, (England; BDH), England and Merck, Darmstadt, and Germany.

\section{B. Methods}

\section{Prolonged Fermentation of Palm Wine}

A portion of the fresh palm wine was allowed to ferment for a prolonged period of 10hours before administration to the rats.

\section{Experimental Design}

A total of twenty (20) albino rats were randomly divided into five (5) groups with each group having four (4) rats each. The palm wine was orally administered to the rats daily for 28 days. Group 1: Normal control rats and were given $1 \mathrm{ml}$ of distilled water. Group 2: $15 \mathrm{ml} / \mathrm{kg}$ body weight of fresh palm wine. Group 3: $15 \mathrm{ml} / \mathrm{kg}$ body weight of prolonged fermented palm wine. Group 4: $30 \mathrm{ml} / \mathrm{kg}$ body weight of fresh palm wine. Group 5: $30 \mathrm{ml} / \mathrm{kg}$ body weight of prolonged fermented palm wine.

\section{Administration of Palm wine to Rats}

The palm wine was administered through oral gavage to the rats based on their body weight using a feeding tube. The administration of palm wine lasted for 28days and on 29th day after an overnight fast their body weight was measured, and blood samples were collected from ocular vein for analysis of biochemical parameters before humanly sacrificing the animals with chloroform.

\section{Determination of Sodium $\left(\mathrm{Na}^{+}\right)$ion Concentration}

The determination of sodium ion was carried out using the methods described by [8].

Principle: The present method is used based on modifications of those first described by [8] in which sodium is precipitated as the triple salt, sodium magnesium uranyl acetate, with the excess uranium then being reacted with ferrocyanide, producing a chromophore whose absorbance varies inversely as the test specimen.

\section{Determination of Potassium $\left(\mathrm{K}^{+}\right)$ion concentration}

The determination of potassium concentration was carried out using the method of [9].

Principle: The amount of potassium is determined by using sodium tetraphenylboron in a specifically prepared mixture to produce a colloidal suspension. The turbidity of which is proportional to potassium concentration in the range of 2 
$7 \mathrm{mEq} / \mathrm{L}$.

\section{Determination of Chloride $\left(\mathrm{Cl}^{-}\right)$ion concentration}

Chloride ion concentration was determined using a direct method based on a modification of the colorimetric method of [10] as outlined in TECO DIAGNOSTIC manual for chloride determination.

Principle: In a reaction with mercuric ions chloride ion form a soluble, non-ionized compound and displaces thiocyanate ions from non-ionized mercuric thiocyanate. Thiocyanate ion released react with ferric ions forming a color complex that absorbs light at $480 \mathrm{~nm}$. The intensity of the color produced is directly proportional to the chloride concentration.

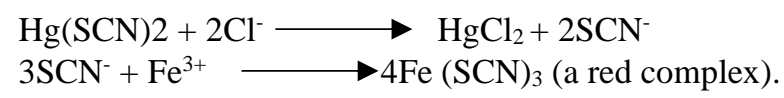

\section{Determination of Urea Concentration}

Serum urea concentration was determined Colorimetrically using Urease-Berthelot Method [11] as outlined in Randox kits for urea determination.

Principle: Urea in serum is hydrolyzed to ammonia in the presence of urease. The ammonia is measured photometrically by Berthelot's reaction.

Urea $+\mathrm{H}_{2} \mathrm{O} \longrightarrow$ Urease $2 \mathrm{NH}_{3}+\mathrm{CO}_{2}$

$\mathrm{NH} 3+$ hypochlorite + Phenol $\longrightarrow$ Indophenol (blue compound).

\section{Determination of Creatinine Concentration}

The modified (using serum sample) Jaffe method [12] for the in vitro determination of creatinine concentration in serum according to the Randox test kits was employed in the determination of creatinine concentration.

Principle: Creatinine in alkaline solution reacts with picric acid to form a colored complex. The amount of the complex formed is directly proportional to the creatinine concentration.

Reagents: $\mathrm{R} / \mathrm{a}=35 \mathrm{mmol} / \mathrm{L}$ Picric acid, $\mathrm{R} / \mathrm{b}=0.32 \mathrm{~mol} / \mathrm{L}$ Sodium hydroxide, $\mathrm{Cal}=177 \mu \mathrm{mol} / \mathrm{L}(2 \mathrm{mg} / \mathrm{dl})$ of creatinine standard.

9. Determination of Low Density Lipoprotein (LDL-C) concentration

The serum level of (LDL-C) was estimated according to protocol of [13] using the equation below:

$$
L D L-C=\text { Total Cholesterol }-\frac{\text { Triglycerides }}{2.2}-\text { HDLc }
$$
$(\mathrm{mmol} / \mathrm{L})$

$$
L D L-C=\text { Total Cholesterol }-\frac{\text { Triglycerides }}{5}-\text { HDLc }
$$
$(\mathrm{mg} / \mathrm{dL})$

10. Determination of High Density Lipoprotein (HDL-C) concentration

The serum level of HDL-C was measured after the method of [14].

Principle: Low density lipoprotein (LDL and VLDL) and chylomicron fractions are precipitated quantitatively by the addition of phosphotungstic acid in the presence of magnesium ions. After centrifugation, the cholesterol concentration in the HDL (high density lipoprotein) fraction, which remains in the supernatant, was determined.

Determination of Triacylglyceride (TAG) concentration: The serum triglyceride concentration was determined after enzymatic hydrolysis of the sample with lipases as described by method of [15].

Principle: Lipase hydrolyses triglycerides sequentially to Di and Monoglycerides and finally to glycerol. Glycerol kinase (GK) using ATP as P04 source converts glycerol liberated to Glycerol-3-Phosphate (G-3-Phosphate). G-3Phosphate Oxidase (GPO) oxidizes G-3-Phosphate formed to Dihydroxy acetone phosphate and hydrogen peroxide is formed. Peroxidase (POD) uses the hydrogen peroxide formed to 4-Aminoantipyrine and Chlorophenol to a pink colored complex. The absorbance of the colored complex is measured at $520 \mathrm{~nm}(500-550 \mathrm{~nm}$ or with green filter) which is proportional to Triglyceride concentration.

$$
\text { Triglycerides }+\mathrm{H}_{2} \mathrm{O} \stackrel{\text { Lipase }}{\longrightarrow} \text { Glycerol + Fatty Acids }
$$

Glycerol + ATP $\stackrel{\text { GK }}{\longrightarrow}$ Glycerol-3-Phosphate + ADP

Glycerol-3-Phosphate+O2 $\stackrel{\mathrm{GPO}}{\longrightarrow}$ Dihydroxyacetone Phosphate $+\mathrm{H}_{2} \mathrm{O}_{2}$

$\mathrm{H}_{2} \mathrm{O}_{2}+4$-Aminoantipyrine+Chlorophenol POD Quinoneimine $+\mathrm{H}_{2} \mathrm{O}$

\section{Determination of Total Serum Cholesterol Using the} Enzymatic Colorimetric Method

The serum total cholesterol was determined after the enzymatic saponification (hydrolysis and oxidation) of the samples as described by [16] as outline in Randox kits.

Principle: The cholesterol is determined after enzymatic hydrolysis and oxidation. The indicator quinoneimine is formed from hydrogen peroxide and 4-aminoantipyrine in the presence of phenol and peroxides.

\section{Cholesterol ester $+\mathrm{H}_{2} \mathrm{O}$ Cholesterol Cholesterol+ Fatty acids esterase}

Cholesterol $+\mathrm{O}_{2}$ Cholesterol Cholestene-3-one $+\mathrm{H}_{2} \mathrm{O}_{2}$ oxidase

$2 \mathrm{H}_{2} \mathrm{O}_{2}+$ phenol +4 -Aminoantipyrine quinoneimine $+4 \mathrm{H}_{2} \mathrm{O}$

\section{Statistical Analysis}

Data obtained was analyzed using one-way ANOVA with the help of IBM Statistical Product and Service Solution (SPSS) Version 21.0. Test for significance was done using Least Significant Difference (LSD) and Duncan test. $\mathrm{P}<0.05$ was considered significant for all values. 


\section{RESUlTS AND DisCUSSION}

\section{A. Results}

\section{Effect of palm wine administration on kidney function parameters}

As shown in Table I below, urea concentration was observed to decrease significantly $(p<0.05)$ in group 2 when compared to the control group (group 1) and increased significantly ( $\mathrm{p}<0.05)$ in group 3 compared to the control group (group 1). However, in group 4, there was no significant $(p>0.05)$ increase in urea concentration compared to the control group. The urea concentration in group 5 showed no significant difference $(\mathrm{p}>0.05)$ when compared to that of the control group (group 1). Similarly, creatinine concentration in group 2 significantly $(p<0.05)$ decreased when compared to the control group and increased significantly $(\mathrm{p}<0.05)$ in group 3 when compared to the control group. The increase in groups 4 and 5 were however not significant $(\mathrm{p}>0.05)$ when compared to the control group. The $\mathrm{Na}^{+}$concentration in group 2 showed no significant difference $(\mathrm{p}>0.05)$ when compared to the control group (group 1). However, the decrease in group 3 and increase in group $5 \mathrm{Na}^{+}$concentration was not significant ( $>0.05)$ when compared to the control group (group 1). Group $4 \mathrm{Na}^{+}$concentration increased significantly $(\mathrm{p}<0.05)$ when compared to that of the control group (group 1). Meanwhile the $\mathrm{K}^{+}$concentration in group 3, 4 and 5 showed no significant $(\mathrm{p}>0.05)$ decrease when compared to the control group (group 1). But group $2 \mathrm{~K}^{+}$concentration increased significantly $(\mathrm{p}<0.05)$ when compared to that of the control group (group 1). The decrease in group 4 and increase in group 5 serum $\mathrm{Cl}^{-}$concentration were not significant ( $>0.05$ ) when compared to the control group (group 1). While group 2 and group $3 \mathrm{Cl}^{-}$concentration showed significant $(\mathrm{p}<0.05)$ increase when compared to the control group (group 1).

\section{Effect of palm wine administration on Lipid Profile of} Rats

As shown in Table II, the total cholesterol (TC) concentration increased non-significantly $(p>0.05)$ in group 2 and decrease in group $4(\mathrm{p}>0.05)$ when compared to that of the control group (group 1). The group 3 and group 5 total Cholesterol concentrations however, showed significant $(\mathrm{p}<0.05)$ decrease when compared to the control group (group 1). Triacylglycerol (TAG) concentration in groups 2 and 4 significantly $(p<0.05)$ increased when compared to the control group. Triacylglycerol (TAG) concentration in group 3 and 5 decreased non-significantly ( $p>0.05)$ when compared to the control group (group 1). Likewise, the high density lipoprotein cholesterol (HDL-C) concentration in group 2 showed no significant $(\mathrm{p}>0.05)$ decrease when compared to that of group 1 and increased significantly $(\mathrm{p}<0.05)$ in group 3, 4 and 5 when compared to the control. For low density lipoprotein cholesterol (LDL-C), the concentration was observed to increase non-significantly $(p>0.05)$ in group 2 compared to the control and decreased significantly $(\mathrm{p}<0.05)$ in group 3, 4 and 5 when compared to the control group.

\begin{tabular}{cccccc}
\multicolumn{6}{c}{ TABLE I: EFFECT OF PALM WINE ADMINISTRATION ON KIDNEY FUNCTION PARAMETERS } \\
\hline Group & $\begin{array}{c}\text { Urea } \\
(\mathrm{mg} / \mathrm{ml})\end{array}$ & $\begin{array}{c}\text { Creatinine } \\
(\mu \mathrm{mol} / \mathrm{L})\end{array}$ & $\begin{array}{c}\mathrm{Na}^{+} \\
(\mu \mathrm{mol} / \mathrm{L})\end{array}$ & $\begin{array}{c}\mathrm{K}^{+} \\
(\mu \mathrm{mol} / \mathrm{L})\end{array}$ \\
\hline Group 1 & $11.04 \pm 0.11^{\mathrm{a}}$ & $0.395 \pm 0.06^{\mathrm{e}}$ & $100.065 \pm 0.75^{\mathrm{h}}$ & $3.945 \pm .064^{\mathrm{k}}$ & $80.090 \pm .254^{\mathrm{m}}$ \\
Group 2 & $10.21 \pm 0.40^{\mathrm{b}}$ & $0.365 \pm 0.17^{\mathrm{f}}$ & $100.065 \pm 2.234^{\mathrm{h}}$ & $4.060 \pm .058^{\mathrm{l}}$ & $86.120 \pm 4.607^{\mathrm{n}}$ \\
Group 3 & $11.70 \pm 0.35^{\mathrm{c}}$ & $0.420 \pm 0.12^{\mathrm{g}}$ & $99.235 \pm 5.629^{\mathrm{h}}$ & $3.920 \pm .058^{\mathrm{k}}$ & $88.570 \pm .497^{\mathrm{n}}$ \\
Group 4 & $11.38 \pm 0.55^{\mathrm{a}}$ & $0.410 \pm 0.23^{\mathrm{e}}$ & $120.090 \pm 10.404^{\mathrm{i}}$ & $3.835 \pm .121^{\mathrm{k}}$ & $79.580 \pm .843^{\mathrm{m}}$ \\
Group 5 & $11.04 \pm 0.05^{\mathrm{a}}$ & $0.400 \pm 0.00^{\mathrm{e}}$ & $106.305 \pm 0.456^{\mathrm{h}}$ & $3.930 \pm 0.81^{\mathrm{k}}$ & $80.105 \pm 2.546^{\mathrm{m}}$ \\
\hline
\end{tabular}

\begin{tabular}{ccccc}
\multicolumn{5}{c}{ TABLE II: EFFECT OF PALM WINE ADMINISTRATION ON LIPID PROFILE } \\
\hline Group & T.CHOL $(\mathrm{mg} / \mathrm{dl})$ & TAG $(\mathrm{mg} / \mathrm{dl})$ & HDL-c $(\mathrm{mg} / \mathrm{dl})$ & LDL-c $(\mathrm{mg} / \mathrm{dl})$ \\
\hline Group 1 & $3.22 \pm 0.05^{\mathrm{a}}$ & $1.96 \pm 0.02^{\mathrm{c}}$ & $0.84 \pm 0.09^{\mathrm{e}}$ & $1.99 \pm 0.05^{\mathrm{h}}$ \\
Group 2 & $3.27 \pm 0.04^{\mathrm{a}}$ & $2.18 \pm 0.10^{\mathrm{d}}$ & $0.73 \pm 0.00^{\mathrm{e}}$ & $2.10 \pm 0.06^{\mathrm{h}}$ \\
Group 3 & $3.13 \pm 0.27^{\mathrm{b}}$ & $1.90 \pm 0.11^{\mathrm{c}}$ & $1.11 \pm 0.22^{\mathrm{g}}$ & $1.64 \pm 0.47^{\mathrm{i}}$ \\
Group 4 & $3.17 \pm 0.04^{\mathrm{a}}$ & $2.19 \pm 0.25^{\mathrm{d}}$ & $1.15 \pm 0.23^{\mathrm{g}}$ & $1.58 \pm 0.14^{\mathrm{i}}$ \\
Group 5 & $2.93 \pm 0.08^{\mathrm{b}}$ & $1.94 \pm 0.08^{\mathrm{c}}$ & $0.99 \pm 0.10^{\mathrm{g}}$ & $1.56 \pm 0.029^{\mathrm{i}}$ \\
\hline
\end{tabular}

\section{B. Discussion}

The outcome of this study indicated that daily ingestion of palm wine in large quantities is a pointer to many deleterious effects on kidney function and lipid profile. This is in agreement with [17] whose study showed elevated levels of serum sodium ion, urea and creatinine of the alcoholics when compared to the control.

The serum urea concentration in group 2 showed a significant $(\mathrm{p}<0.05)$ decrease when compared with the control group. This contradicts the report of [18] whose work showed a high level of serum urea among palm wine drinkers. The increase in serum urea concentration observed in group 3 indicate that high alcoholic concentration due to prolonged fermentation of the palm wine may have adverse effects on the ability of the kidney to excrete nitrogenous metabolic wastes. This finding agrees with [17] who showed significant elevation of serum urea concentration among alcoholics.
Ammonia generated from the deamination of amino acids is usually converted to urea in the liver. The synthesized urea is freely filtered from the glomeruli and then excreted out of the body.

Blood creatinine is usually a waste product of muscle metabolism formed by the non-enzymatic dehydration of muscles. It is freely cleared and excreted by normal kidneys and serves as an important indicator of renal function status. The serum creatinine concentration in group 2 showed a significant $(\mathrm{p}<0.05)$ decreased when compared to the control. This is in agreement with [18] who observed a decreased in creatinine due to palm wine administration in rats. This could be as a result depleting muscle mass and/or malnutrition. However, group 3 serum creatinine concentration of the rats showed a significant $(\mathrm{p}<0.05)$ increase when compared with control group. This is in agreement with [17] who showed that high intake of alcoholic beverage caused a significant increase $(p<0.05)$ in the serum creatinine concentration of a 
cohort of alcoholics. This elevation could have resulted from deterioration in the kidney's (caused by chronic alcohol abuse) ability to perform its excretory functions of getting rid of creatinine from the body consequent upon the reduction in creatinine clearance from the blood.

The kidney is a vital organ in the body that is highly vulnerable to the devastating effects of chronic alcohol abuse. Functions of the kidney are to regulate both the volume and the composition of the body's fluid and electrolytes such as sodium, potassium, and chloride ions. These ions have to be balanced in the blood stream to maintain healthy metabolic process [18]. However, alcohol's ability to increase urine volume alters the body's fluid level and produces disturbances in the electrolyte concentration [19]. These effects vary depending on factors such as the amount of alcohol and duration of drinking, the presence of other diseases and nutritional status of individuals. Chronic alcohol abuse destroys the delicate balance of ions and water in the body by altering the filtering, and reabsorption abilities of the kidneys [20]. It is observed that transient defects in renal tubular function are common among individuals with chronic alcoholism and may contribute to their abnormalities of serum electrolyte and blood acid-base profile [21].

For serum electrolytes, the result reflected that while the serum sodium $\left(\mathrm{Na}^{+}\right)$concentration of group 2 showed no significant difference, that of group 3 was shown to decreased non-significantly $(\mathrm{p}<0.05)$ and group 5 increased nonsignificantly ( $p>0.05)$ when compared with the control group. However, group 4 showed significant $(p>0.05)$ increased when compared with the control group. This finding is in harmony with [18] who report that acute administration of alcoholic beverage (i.e., palm wine) causes not only a marked urinary flow but also consistent fall in the excretion of $\mathrm{Na}^{+}$, $\mathrm{Cl}^{-}$, and $\mathrm{K}^{+}$in humans. This may be due diuretic activity of the kidney caused and/or induced by alcohol (ethanol) in the palm wine. For serum potassium $\left(\mathrm{K}^{+}\right)$concentration, no significant $(\mathrm{p}>0.05)$ decreased was observed in group 3,4 , and 5 when compared to their control group. However, group 2 apparently showed a significant $(\mathrm{p}<0.05)$ increased when compared with the control group. This is in contrast with [19] and [18] who both reported a low serum level of potassium ion concentration among different groups of alcoholics. Furthermore, serum chloride concentration of group 4 showed no significant $(\mathrm{p}>0.05)$ decrease and group 5 showed no significant $(\mathrm{p}>0.05)$ increase when compared with control. However, group 2 and group 3 showed significant $(p<0.05)$ increased each when compared with the control group.

The total cholesterol (TC) concentration increased nonsignificantly $(p>0.05)$ in group 2 and decreased in group 4 non-significantly $(p>0.05)$ when compared to that of the control group. In contrast, group 3, and group 5 total Cholesterol concentrations however, showed significant $(\mathrm{p}<0.05)$ decrease when compared to the control group. The low level of total cholesterol may have been influenced by dietary compositions and other metabolic factors. Elevated serum total cholesterol may exacerbate coronary heart diseases. Serum triacylglycerol (TAG) concentration in group 3 and 5 showed a non-significantly $(p>0.05)$ decreased, those of groups 2 and 4 significantly $(\mathrm{p}<0.05)$ increase when compared to the control group. The elevated triacylglycerol
(TAG) in group 2 and 4 could be due to the fact that alcohol administration may lead to a drop in the levels of mitochondrion $\mathrm{NAD}^{+}$, required for the oxidization of fatty acids, causing an inhibition of acetoacetate metabolism and fatty acid oxidization in many organs such as the liver. The rise of $\mathrm{NADH} / \mathrm{NAD}^{+}$ratio favours more fatty acid production and can lead to elevated levels of triacylglycerides. Alcohol consumption has been implicated to cause a rise in triglycerides and VLDL production, which possibly explains the elevation observed in group 2 and 4. Likewise, the high density lipoprotein cholesterol (HDLc) concentration in group 2 showed no significant $(p>0.05)$ decrease when compared to that of the control. However, in groups 3, 4 and 5 , its concentrations increased significantly $(\mathrm{p}<0.05)$ when compared to the control group. This signified an increase in lipoprotein lipase ratio; as the rate of lipid breakdown increases, VLDL apoprotein convertion to HDL and cholesterol flow would also rise.

For low density lipoprotein cholesterol (LDL-C), the concentration was observed to increase non-significantly $(p>0.05)$ in group 2 compared to the control and decreased significantly $(\mathrm{p}<0.05)$ in group 3,4 and 5 when compared to the control group. The decline of LDL cholesterol in palmwine administered rats may be due to the fact that alcohol consumption generates an increasing activity of paraoxonase. Paraoxonase confers to HDL-C antioxidizing properties by making possible the hydrolysis of LDL-C oxidized phospholipids [22]. Cholesterol level reduction, especially LDL cholesterol, which could be a favorable dynamic for a healthy heart, a situation that may have been accomplished by either diet, palm wine or both.

\section{CONCLUSION}

In this study, we administered fresh and prolonged fermented palm-wine to albino rats for 28 days and analyzed the serum changes in the kidney function parameters and lipid profile. The outcome of this study revealed that the administered doses of fresh and prolonged fermented palmwine may have adversely affected the kidney function indices such as urea, creatinine, potassium ion chloride ion, sodium ion, and lipid profile such as triacylglycerol, High density lipoprotein cholesterol (HDL-C) of albino rats by significantly raising their concentrations and decreasing total cholesterol and low density lipoprotein cholesterol (LDL-C).

\section{ACKNOWLEDGMENT}

We would like to thank Prof. T.O Bamidele for providing an enabling environment in the animal house and for granting us access to the laboratory during the analyses.

\section{REFERENCES}

[1] N. Okafor. (1975). Microbiology of Nigerian palm wine with pasrticular reference to bacteria. J. Appl. Bact. [online]. 38. pp 81-88.

[2] S. I. Faparusi and O.Bassir (1972). Factors affecting palm wine. Period of Tapping. West African Journal of biological and applied chemistry [online]. 15 pp. 24-32. 20.

[3] S. Faparusi (1973). The Microbiology of burukutu beer. Journal of basic Microbiology [online]. 7. Pp. 23-25.

[4] K. Theivendirarajah and R.K. Chrystopher. (1977). Studies on Palm 
yrah (Borassus flabellifer) palm sap. Proceedings of the Sri Lanka Association for the Advancement of Science.1987.39, 64 (abstract).

[5] O. Obire (2005). Activity of Yeast Species in Palm Sap Obtained from Three Areas in Edo State, Nigeria. Applied Science Enviromental Management, [online]. 9 pp. 25-30.

[6] G.S. Haruna O. B. Nwaikuku B.A. James, N. Musa, and R. Valentine. (2020). Changes in Some Biochemical Parameters and Body Weights of Healthy Albino Rats Following Palm-wine Administration, Asian Journal of Research in Biochemistry [online]. 7(4). pp. 35-44.

[7] O. Bassir (1962). Observations on the fermentation of palm wine. West afric. J. Biol. and Appl. Chem. [online]. 6. pp 20-25.

[8] R.F. Maruna, (1958). Colometric determination of sodium in human serum and plasma. Clin. Chem. Acta, [online]. 2. pp. 581-581.

[9] N.W. Tietz (1999). Clinical guide to laboratory tests. 3rd Edition. Philadelphia, PA: WB Saunders Company.

[10] Skeggs, L.T. and Hochstrasser, H.C. (1964). Thiocyanate (colometric) Method of Chloride Estimation. J. Clin. Chem. [online]. 0. p 918.

[11] M.W. Weatherburn (1967) Phenol Hipochlorite Reaction for Determination of Ammonia. Analytical Chemistry, 39. pp 971-974.

[12] K.G. Blass, R. J. Thiebert and L.K. Lam (1974). A study of the mechanism of the Jaffe Reation. Journal of Clincal Chemistry and Clinical Biochemistry [online].12. pp. 336-343.

[13] W.T. Friedewald, R.T Levy and D.S. Frederickson (1972). Estimation of the concentration of low-density lipoprotein cholesterol in plasma without use of the preparative ultracentrifuge. Clin. Chem. [online]. 18. pp. 499-502.

[14] R.G. Wacnic and J.J. Alber (1978). A comprehensive evaluation of the heparin manganese precipitation procedure for estimating high density lipoprotein cholestsrol. Journal of Lipid Research [online]. 19. pp. 6576.

[15] N.W. Tietz (1990). Clinical Guide to Laboratory Test, Second Edition W.B. Saunders Company, Philadelphia, U.S.A. pp. 554-556.

[16] C.C. Allain L.S. Poon, C.S. Chan, W. Richmond and P.C. Fu (1974). Enzymatic determination of total serum cholesterol, Clin. Chem. [online]. 20(4), pp. 470-5.

[17] U. Aniyom, D. E. O. Dien, B. Atim-Antai and E.O. Eme. (2018). Effect of Consumption of Artesunate and/or Palm Wine on Serum Electrolytes, Urea, Creatinine and Estimated Glomerular Filtration Rate, Annual Research \& Review in Biology[online]. 28(1). pp. 1-7.

[18] G.I Eze, and V.O. Ekundina. (2018). The Effects of Carbonated Alcoholic Herbal Beverage on Selected Hepato-Renalfunct 1on Indices, Some Haematological Parameters and Histopathology Of Adult Male Wistar Rats, Ann Bioned Sci. [online]. 17(1):86-99

[19] P. Chandini, and M. John. (2015). Serum Electrolytes Levels in Patients with Alcohol Dependence Syndrome, International Journal of Contemporary Medical Research [online], 4(5). pp. 77-83.

[20] L.C. Costello-Boerrigter, G. Boerrigter, and J.C. Burnett. (2003). Revisiting salt and water retention: New diuretics, aquaretics and natriuretics. Alcohol Clinical and Experimental Research [online]. 28 pp. $1550-1568$.

[21] F.M. Chung Y.H. Yang, S.J. Shin, and J.C. Tsai. (2005). Effect of alcohol consumption on estimated glomerular filtration rate and creatinine clearance rate. Nephrology, Dialysis and Transplant [online]. 20. pp. $1610-1616$.

[22] D. Bonnefont-Rousselot, P. Therond, J.L Beaudeux, J. Peynet, A. Legrand, and J. Delattre. (1999). High density lipoproteins (HDL) and the oxidative hypothesis of atherosclerosis. Clin Chem Lab. Med. [online]. 37:939-948. 